\title{
Factors Affecting Students' Attitude toward Mathematics: A Structural Equation Modeling Approach
}

\author{
Shamila Dewi Davadas ${ }^{1}$, Yoon Fah Lay ${ }^{1 *}$ \\ ${ }^{1}$ Universiti Malaysia Sabah, Faculty of Psychology and Education, Kota Kinabalu, Sabah, MALAYSIA
}

Received 25 May 2017 - Revised 2 September 2017 - Accepted 24 October 2017

\begin{abstract}
Students' attitude towards mathematics is affected by factors such as parental influences, teacher affective support and classroom instruction. The purpose of this research was to examine the inter-relationships between these factors and effects on attitude towards mathematics using a partial least squares-structural equation modeling approach. A survey was carried out with a sample of 318 Form Four students from Sabah, Malaysia. The questionnaire consists of four scales: Perceived Parental Influences, Teacher Affective Support, Classroom Instruction and Attitude towards Mathematics. IBM SPSS 19.0 and Smart PLS 2.0 were used to analyze the measurement and structural models. The results showed that with the exclusion of some indicators from the scales, the measurement models showed acceptable reliability and validity. The structural model has moderate predictive relevance but the inter-relationships of the constructs in the structural model were significant. Teacher affective support and classroom instruction predict attitude towards mathematics more than parental influences.
\end{abstract}

Keywords: attitude towards mathematics, classroom instruction, perceived parental influences, teacher affective support, structural equation modeling, partial least squares

\section{INTRODUCTION}

Generally, Malaysian students' beliefs of their mathematical competency were high and positive (Tarmizi \& Tarmizi, 2010). However, their achievement in mathematics has been declining in the past years. Beginning with a higher than international average score for Mathematics and Science in the Trends in International Mathematics and Science Study (TIMSS) in 1999, Malaysian students' achievement continued to decline (Mullis, Martin, Foy, \& Arora, 2012). Malaysian eighth graders' mathematics scores in TIMSS dropped from 508 points in 2003 through 494 points in 2007 to 451 points in 2011 although there was an increase of 25 points to 465 in TIMSS 2015. Due to the declining students' achievement in TIMSS, many changes in the curriculum have been introduced, such as the Malaysia Education Development Plan, School Based Assessment, Standard Curriculum for Secondary Schools, and the Understanding through Design Project.

Eighth grade (Form 2) students' disposition towards mathematics was measured by nine statements on the Students Like Learning Mathematics scale in both TIMSS 2011 and TIMSS 2015. 39\% of Malaysian students responded that they "Very much like learning Mathematics" in 2011 compared to only $28 \%$ in $2015.16 \%$ of students responded that they "Do not like learning Mathematics" in 2015 compared to 15\% in 2016: showing an increase towards the "dislike" feeling (Mullis et al., 2012; Mullis et al., 2016).

Students' attitude towards mathematics were found to be significantly related to their achievement in this subject (Lipnevich et al., 2011; Lubienski, Lubienski, \& Crane, 2012; Moenikia \& Zahed-Babelan, 2010; Woon, 2005). In this study, three factors relating to attitude towards mathematics were examined. These are perceived parental influences (Cao, Bishop, \& Forgasz, 2006), teacher's affective support (Sakiz, Pape, \& Hoy, 2012; Sakiz, 2007) and classroom instruction (Abu Bakar et al., 2010; Tessema, 2010). 


\section{Contribution of this paper to the literature}

- Perceived parental influences, teacher affective support, and classroom instruction are significant predictors of attitude toward mathematics.

- The proposed structural model supported by PLS analysis was able to predict the inter-relationships of the constructs on a moderate level.

- The moderate predicting relevance and effect size implied that attitude towards mathematics is multifaceted with a likelihood of other contributing factors such as students' socio-economic status, gender and past achievements.

The general objective of the study is to revalidate the instruments in a Malaysian context and to propose a structural model that will portray the relationship between parental influences, teacher affective support and classroom instruction with students' attitude towards mathematics. The specific objectives are:

i. to examine the relationship between parental influences, teacher affective support and classroom instruction with students' attitude towards mathematics;

ii. to investigate the predictive effects of parental influences, teacher affective support and classroom instruction on students' attitude towards mathematics;

Based on the research questions, the following hypotheses have been developed:

$\mathbf{H}_{\mathbf{1}}$ : There is a positive relationship between students' Perceived Parental Influences and their Attitude towards Mathematics.

$\mathbf{H}_{\mathbf{2}}$ : There is a positive relationship between Teacher Affective Support and students' Attitude towards Mathematics.

$\mathbf{H}_{3}$ : There is a positive relationship between Classroom Instruction and students' Attitude towards Mathematics.

$\mathbf{H}_{4}$ : Teacher Affective Support is a mediator in the relationship between students' Perceived Parental Influences and their Attitude towards Mathematics.

\section{LITERATURE REVIEW}

\section{Social Cognitive Theory}

From a social learning perspective, human nature is characterized as a vast potentiality that can be fashioned by direct and vicarious experience into a variety of forms within biological limits (Bandura, 1977). Modeling serves as the principal model of transmitting new forms of behavior. Children's math attitudes form as a result of environmental influences, especially those that occur in interactions with parents (Jacobs et al., 2005; Cao, Forgasz, \& Bishop, 2006) and teachers (Gunderson et al., 2012).

People regulate their behaviour based on their discernment of the relationships between situations, actions, and outcomes (Bandura, 1977). People avoid things that have been associated with aversive experiences, but like and look for things that have pleasant associations. In the same manner, students form positive attitudes when presented with interesting teaching strategies (Yang, 2015).

\section{Eccles Expectancy Value Theory}

Expectancies and values are assumed to directly influence achievement choices. Expectancies and values also influence performance, effort and persistence. Expectancies and values, in turn, are assumed to be influenced by task-specific beliefs such as ability beliefs, the perceived difficulty of different tasks, and individuals' goals, selfschema, and affective memories. The social cognitive variables such as ability beliefs, individuals' goals and selfschema are influenced by individuals' perceptions of their own previous experiences and a variety of socialization influences (Wigfield \& Eccles, 2000). In this study, socializers refers to either teachers or parents who influence the children's learning.

\section{Cognitive Load Theory}

Certain Classroom Instruction (CI) methods seek to reduce the load for the working memory while other methods increase the difficulty level of the content by overloading the working memory (Sweller, Ayres, \& Kalyuga, 2011). Students' may feel intimidated by information presented inappropriately and may lose interest in 
a particular subject. It seems necessary to pay more attention to choosing and carrying out the instruction method (Aliasgari, Riahinia, \& Mojdehavar, 2010).

\section{Students' Attitude toward Mathematics}

Attitude is defined as a mental set or disposition, readiness to respond and the psychological basis of attitudes, their permanence, learned nature and evaluative character (Moenikia \& Zahed-Babelan, 2010). In the context of mathematics, attitude should be viewed as a predisposition to respond in a favourable or unfavourable way to mathematics (Moenikia \& Zahed-Babela, 2010).

Studies showed a linkage between attitude to success in mathematics (Lipnevich et al., 2011; Lubienski et al., 2012; Moenikia \& Zahed-Babelan, 2010). It is important to develop a positive attitude towards mathematics because there is a correlation between students' attitude towards mathematics and their mathematical results (Bilican, Demirtasli, \& Kilmen, 2011; Chiesi \& Primi, 2009; Dumais, 2009; Lipnevich et al., 2011; Marchis, 2011; Singh \& Imam, 2013; Author, and Khoo, 2010). Students in general tend to dislike mathematics more than other subjects (Poffenberger \& Norton, 1959). However, Mathematics is a compulsory subject in primary and secondary schools in most countries including Malaysia.

\section{Factors Affecting Students' Attitude toward Mathematics}

In this study, three factors relating to attitude towards mathematics are examined: these are parental influences (Kerr, 2007; Mahamood et al., 2012), teacher affective support (Johnson, 2000; Marchis, 2011; Sakiz et al., 2012) and classroom instruction (Bakar et al., 2010). Perceived Parental Influences (PPI). One of the factors affecting attitude towards mathematics is parental influence (Kerr, 2007; Mahamood et al., 2012). Parental influences can be either direct or indirect. Direct influences include parents helping their children with mathematics difficulties while indirect parental influences include parental encouragement, parental expectation and their own attitude towards mathematics (Cai, Moyer, \& Wang, 1997). In a study by Mahamood et al. (2012) regarding parental attitude and involvement in children's education specifically parental aspiration among Form Four students in Selangor, Malaysia, it was revealed that parental involvement is a positive and powerful source of influence towards the achievement of adolescents.

Teacher Affective Support (TAS). Teachers' support is also necessary to encourage positive attitudes towards mathematics (Marchis, 2011; Sakiz et al., 2012). Teachers' strong influence on students' beliefs in their mathematical competency suggest the importance of the teacher's role in mathematics classrooms which leads to improvement in students' mathematics performance (Berends, Goldring, Stein, \& Cravens, 2012; Charalambous, Panaoura, \& Philippou, 2009; Johnson, 2000). The affective dimensions of teacher support significantly affect students' academic, emotional, behavioural, and motivational outcomes in educational environment (Sakiz, 2007). Components in TAS are specified as caring, respect, concern for, and interest in students, valuing, listening, fair treatment, encouragement, and high expectations (Sakiz, 2007).

According to Rodriguez-Brown (2009) one of the contributions that schools and teachers can make that supports children's transition from home to school is to invite parents to visit the classroom anytime during a preset day. In Rodriguez-Brown (2009), teachers' activities were found to be unique but effective in conveying to parents the teacher's acceptance for the knowledge the parents already have as well as their involvement in their child's instruction. The context of family and community are critical to a child's school learning but the school is not impotent in affecting the beliefs and behaviours of adults outside the school who influence the child's learning and development (Redding, 2010). The school and the families it serves can define their own community with its sense of purpose, patterns of relationship, and expectations of all its members according to their roles. Therefore, TAS is also tested as a mediator between PPI \& Attitude towards mathematics (ATM) in this study.

Classroom Instruction (CI). Classroom processes serve as a mechanism through which teacher attitudes, student attitudes, and student's achievement-related behaviour can affect student achievement (Reyes \& Stanic, 1988). CI is a broad term that covers instructional strategies (Tessema, 2010) and materials and equipment (Mullens \& Gayler, 1999) used in the classroom during the teaching and learning process. The choice of instructional strategy can influence students' affect towards mathematics (Hodges \& Kim, 2013; Hosack, 2006: 47; Schukajlow et al., 2012). Teacher attitude, student attitude and student's achievement-related behaviour may change as teachers and students interact in the classroom (Reyes \& Stanic, 1988). Classroom instructional strategies that provide students with multiple opportunities to learn are modeling, student-centered, cooperative-learning, collaborative discussion, and spatial thinking (Tessema, 2010). These instructional practices have the potential to impact students' attitudes towards mathematics positively. 


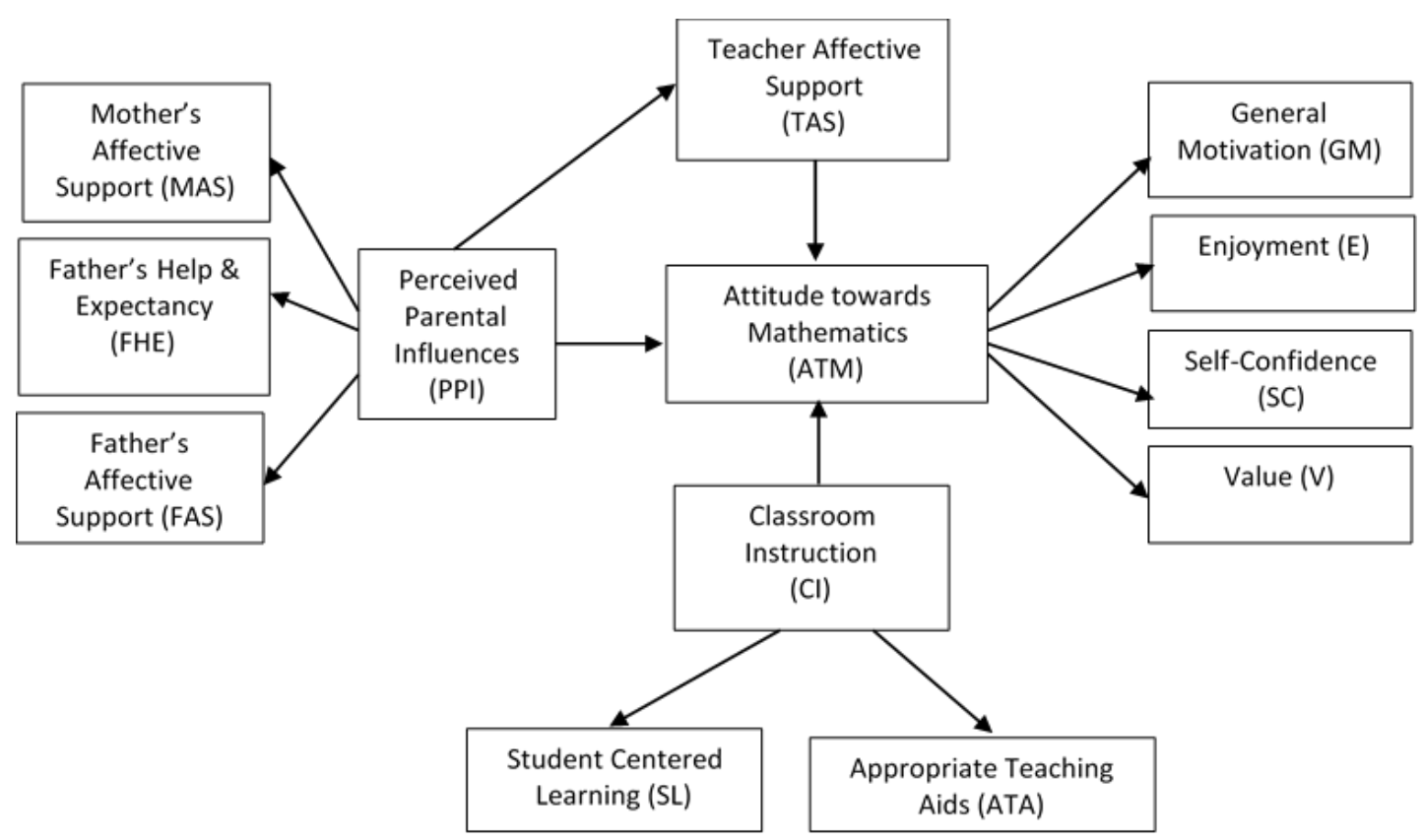

Figure 1. The Conceptual Framework

\section{The Conceptual Framework}

The conceptual framework for this study is derived from past studies (Haladyna, Shaughnessy, \& Shaughnessy, 1983; Reyes \& Stanic, 1998) and supported with the theoretical framework which identifies factors related to students' attitude towards mathematics. Parental influences, teacher affective support and classroom instruction are presumed to be directly related to students' attitude towards mathematics. Figure 1 presents the conceptual framework which serves as the proposed structural model for this research.

\section{RESEARCH METHODOLOGY}

The research is designed to determine the direct, indirect and total effects of factors that affect students' attitude towards mathematics. This study is a quantitative and cross-sectional study, employing the use of questionnaire to collect data. Survey is a common method to measure students' attitude towards mathematics (Etuk, Afangideh, \& Uya, 2013; Marchis, 2011; Tahar, Ismail, Zamani, \& Adnan, 2010 Tapia \& Marsh, 2000). A total of 318 Form Four students from one school in Kota Kinabalu, Sabah participated in this study. Data from the questionnaire were keyed-in using SPSS Version 19 software and analysed with SmartPLS 2.0 M3 (Ringle et al., 2004). A questionnaire was developed using four existing scales: Perceived Parental Influences (Cao et al., 2006), Teacher Affective Support (Sakiz, 2007), Classroom Instruction (Tessema, 2010) and Attitude towards Mathematics Inventory (Tapia, 1996). The scales were selected based on appropriateness for the context of this study and no repetitions among items measuring different constructs. Permission was obtained from the original authors whose scales have been adopted in this research.

The Perceived Parental Influences (PPI) scale consists of 16 items.

Sample items:

1. My mother checks my maths homework frequently.

2. My mother asks me about my assessment results in maths.

The Classroom Instruction (CI) scale consists of 15 items.

Sample items:

Instruction: Identify if the teaching and learning method below has been used in your class. If it has been used, select to what extent it has been useful in your learning (scale 1 - 10).

1. Lecture and note taking.

2. Class discussions.

The ATM scale (Tapia, 1996; Tapia \& Marsh, 2000; Tapia \& Marsh, 2002) consists of 40 items. 
Sample items: (Negative items) Scale 1 (Totally Disagree) - 10 (Totally Agree).

1. I am always under a terrible strain in a math class.

2. When I hear the word mathematics, I have a feeling of dislike.

The Teacher Affective Support (TAS) scale consists of 9 items.

Sample items:

1. My math teacher believes that I can do a good job in math.

2. I can talk to my math teacher about things that are bothering me.

\section{RESEARCH FINDINGS}

\section{Demography}

The sample consists of 318 (all) Form 4 students from 1 school in Kolombong, Kota Kinabalu district. The school is categorized as an urban school in the Education Department (PPD) database. A majority of the students' fathers are employed as truck drivers (13.8\%) and general workers (18.2\%). 17.3\% of the students' fathers and $77.0 \%$ of the students' mothers are unemployed. The sample consists of 140 boys and 178 girls. Out of these, 21 students $(6.6 \%)$ had failed their PT3 Mathematics paper. The PT3 Mathematics paper is one of the compulsory papers for Form Three students. It is a school based assessment. The PT3 results are Grades A, 'excellent' through E, 'minimum standard achieved'. F represents 'fail'. A majority of the students had received an E (43.4\%).

\section{Assessment of the Measurement Model}

The assessment of the measurement model is based on the convergent validity and discriminant validity (Lewis et al., 2005, Straub et al., 2004). Convergent validity is the degree to which multiple attempts to measure the same concept are in agreement. It is based on factor loading, composite reliability (CR) and average variance extracted (AVE) (Chin, 1998; Hulland, 1999). According to Hair et al. (2014), factor loading should be greater than 0.70 to provide statistical significance to ensure the model is fit. Composite reliability (CR) value depicts the degree to which the construct indicators indicate the latent construct, which must exceed 0.70 . On the other hand, AVE value should be more than 0.5 (Hair et al., 2014). Internal consistency is evaluated based on Cronbach's Alpha coefficient. Constructs with high coefficient values imply that the items within the constructs have the same range and meaning (Cronbach, 1971). The coefficient should be at least 0.7 in the early stage and values of 0.8 or 0.9 for more advanced stages of research. Values below 0.6 indicate lack of reliability (Nunnally \& Bernstein, 1994).

Discriminant validity is the degree to which the measures of different concepts are distinct. It tests whether the items do not unintentionally measure something else (Urbach \& Ahlemann, 2010) which can be determined with Fornell-Lacker's method (Fornell \& Lacker, 1981). The analysis is valid if the square root of AVE for each latent construct is higher than correlations of any other latent construct (Fornell \& Larcker, 1981; Hair et al., 2011).

Measurement model assessment. Figure 2 presents the first-order measurement model which shows subdimensions in each scales of the latent variables. Perceived Parental Influences (PPI) and Classroom Instruction (CI) are drawn as reflective constructs based on the decision criteria of reflective or formative measurement model by Jarvis et al. (2003) and MacKenzie et al. (2005). The PPI and CI constructs are made up of indicators which are highly correlated and the removal of one or two indicators does not alter the meaning of the construct. 


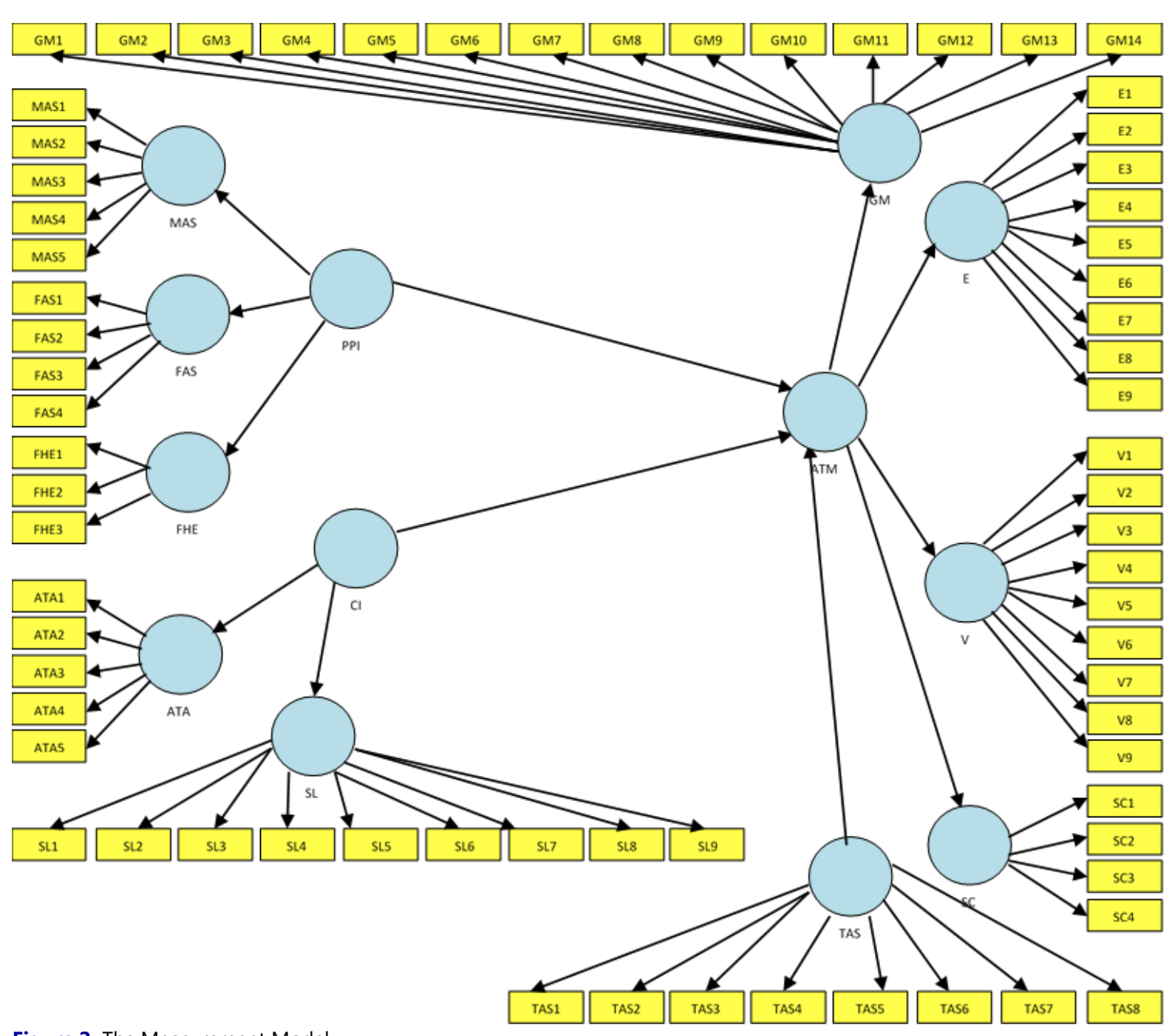

Figure 2. The Measurement Model

Table 1 presents the result of indicator outer loading assessment. All the indicators of the first order constructs ATA, FAS and FHE have outer loadings of more than 0.7. The other constructs consisted of some indicators with outer loading less than 0.7. Thus, 24 indicators were removed, resulting in all indicators with outer loading more than 0.7. The second order construct PPI is reflected by three first order constructs: Mother's Affective Support, MAS (5 items), Father's Affective Support, FAS (4 items) and Father's Help \& Expectation, FHE (5 items). The second order construct $\mathrm{CI}$ is reflected by two first order constructs: Appropriate Aids, ATA (5 items) and Studentcentered Learning, SL (9 items). The construct TAS remained as a first order construct with 9 items. The endogenous construct, ATM was reflected by four first order constructs: Self-Confidence, SC (4 items), General Motivation, GM (14 items), Value, V (9 items) and Enjoyment, E (9 items). 
Table 1. Indicator Outer Loading Assessment

\begin{tabular}{|c|c|c|c|}
\hline Construct & No. of Indicators & Outer Loading ( $\mathrm{OL}$ ) & Decision \\
\hline ATA & 5 & All indicators with $\mathrm{OL}>0.7$ & All indicators are accepted \\
\hline $\mathrm{E}$ & 9 & $\begin{array}{l}\text { Eight indicators with } \mathrm{OL}>0.7 \text {. One indicator with } 0.6 \\
\qquad \mathrm{OL}<0.7\end{array}$ & One item considered for removal \\
\hline FAS & 4 & All indicators with $\mathrm{OL}>0.7$ & All indicators are accepted \\
\hline FHE & 3 & All indicators with $\mathrm{OL}>0.7$ & All indicators are accepted \\
\hline GM & 14 & $\begin{array}{l}\text { Five indicators with } \mathrm{OL}>0.7 \text {. Nine indicators with } \\
\qquad 0.5<\mathrm{OL}<0.7\end{array}$ & $\begin{array}{c}\text { Nine items were considered for } \\
\text { removal }\end{array}$ \\
\hline MAS & 5 & $\begin{array}{l}\text { Two indicators with } \mathrm{OL}>0.7 \text {, three indicators with } \\
\qquad 0.6<\mathrm{OL}<0.7\end{array}$ & Three items considered for removal \\
\hline SC & 4 & $\begin{array}{l}\text { Three indicators with } \mathrm{OL}>0.7 \text {, One item with } \\
0.6<\mathrm{OL}<0.7 \text { and one with } \mathrm{OL}<0.4\end{array}$ & $\begin{array}{l}\text { One item considered for removal, } \\
\text { another item was definitely removed }\end{array}$ \\
\hline $\mathrm{SL}$ & 9 & Five items with $\mathrm{OL}>0.7$, four items with $0.6<\mathrm{OL}<0.7$ & Four items considered for removal. \\
\hline TAS & 8 & Four items with $\mathrm{OL}>0.7$, four items $0.6<\mathrm{OL}<0.7$ & Four items considered for removal \\
\hline $\mathrm{V}$ & 9 & Six items with $\mathrm{OL}>0.7$, three item with $0.6<\mathrm{OL}<0.7$ & Three item considered for removal \\
\hline
\end{tabular}

Table 2. The Composite Reliability and AVE of the Measurement Model

\begin{tabular}{cll}
\hline Construct & CR & AVE \\
\hline ATA & .909 & .666 \\
\hline E & .929 & .623 \\
\hline FAS & .866 & .619 \\
\hline FHE & .854 & .661 \\
\hline GM & .902 & .648 \\
\hline MAS & .849 & .737 \\
\hline SC & .874 & .698 \\
\hline SL & .856 & .543 \\
\hline TAS & .858 & .547 \\
\hline V & .901 & .602 \\
\hline
\end{tabular}

Table 3. Results of the Fornell-Larker Analysis of the Measurement Model

\begin{tabular}{|c|c|c|c|c|c|c|c|c|c|c|}
\hline & ATA & $\mathbf{E}$ & FAS & FHE & GM & MAS & SC & SL & TAS & $\mathbf{v}$ \\
\hline ATA & .816 & & & & & & & & & \\
\hline$E$ & .095 & .789 & & & & & & & & \\
\hline FAS & .088 & .105 & .787 & & & & & & & \\
\hline $\mathrm{FHE}$ & .193 & .055 & .519 & .813 & & & & & & \\
\hline $\mathrm{GM}$ & .195 & .463 & .294 & .240 & .805 & & & & & \\
\hline MAS & .172 & .224 & .395 & .470 & .388 & .858 & & & & \\
\hline SC & .296 & .288 & .220 & .289 & .588 & .299 & .835 & & & \\
\hline$S L$ & .286 & .331 & .414 & .256 & .504 & .448 & .321 & .737 & & \\
\hline TAS & .122 & .277 & .437 & .246 & .445 & .374 & .313 & .623 & .740 & \\
\hline V & .027 & .311 & .413 & .138 & .513 & .402 & .242 & .497 & .550 & .776 \\
\hline
\end{tabular}

Table 2 presents the summary result of composite reliability (CR) and average variance extracted (AVE) for each of the constructs. The result showed that CR for each construct ranges from .854 to .929 which is more than the cut-off value of 0.7 . Therefore, the analysis indicated that the items used to measure the constructs have satisfactory result. The AVE determines the convergent validity of the measurement model. All constructs showed AVE more than 0.5 , indicating acceptable convergent validity.

Table 3 presents the model's discriminant validity based on Fornell-Larker approach whereby the square root of AVE are calculated manually and compared to the inter-correlations of among the constructs. The bolded elements in the Table 3 represent the square root of the AVE and non-bolded values represent the inter-correlations value between constructs. It is indicated that all off-diagonal elements are lower than square roots of AVE, hence confirming that the discriminant validity of the measurement model was met.

Structural model assessment. Figure 3 presents the first-order measurement model which shows subdimensions in each scales of the latent variables. 


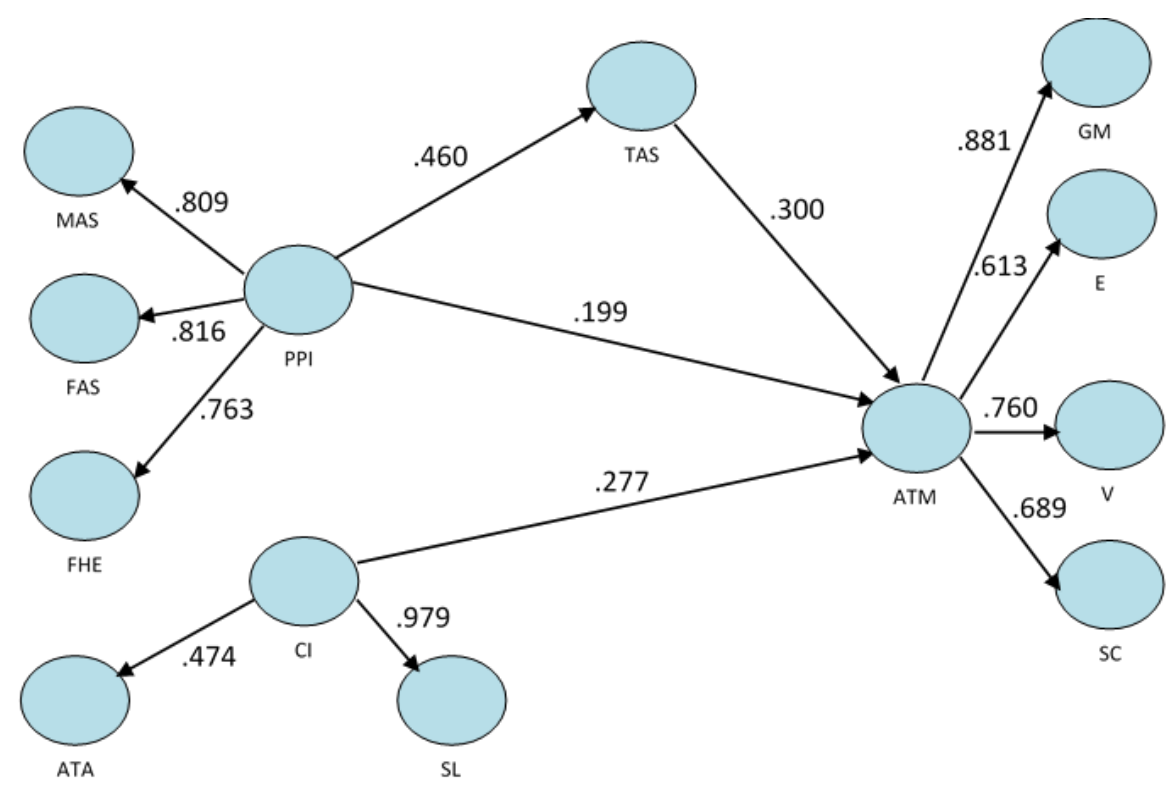

Figure 3. The Structural Model

Table 4. Indicator Loadings, CR and AVE of the Second-Order Measurement Model

\begin{tabular}{|c|c|c|c|c|c|}
\hline Construct & Items / Indicators & Loading & T-value & CR & AVE \\
\hline \multirow{2}{*}{$\mathrm{Cl}$} & $\mathrm{SL}$ & .979 & 64.532 & \multirow{2}{*}{.828} & \multirow{2}{*}{.551} \\
\hline & ATA & .474 & 4.249 & & \\
\hline \multirow{3}{*}{ PPI } & FAS & .816 & 28.347 & \multirow{3}{*}{.721} & \multirow{3}{*}{.592} \\
\hline & FHE & .763 & 18.458 & & \\
\hline & MAS & .809 & 32.017 & & \\
\hline \multirow{5}{*}{ TAS } & TAS1 & .722 & 19.616 & \multirow{5}{*}{.838} & \multirow{5}{*}{.634} \\
\hline & TAS2 & .746 & 21.215 & & \\
\hline & TAS3 & .747 & 22.553 & & \\
\hline & TAS7 & .714 & 16.477 & & \\
\hline & TAS8 & .769 & 24.923 & & \\
\hline \multirow{4}{*}{ ATM } & GM & .881 & 51.433 & \multirow{4}{*}{.858} & \multirow{4}{*}{.547} \\
\hline & $\mathrm{E}$ & .613 & 6.963 & & \\
\hline & $\mathrm{V}$ & .760 & 22.555 & & \\
\hline & SC & .689 & 15.160 & & \\
\hline
\end{tabular}

Table 4 shows the indicator loadings, the composite reliability and AVE of the second-order measurement model. Latent variable scores are determinate in PLS path analysis; therefore latent variable scores for lower-order latent variables were obtained (Chin, 1998) and subsequently used as manifest variables for the higher-order latent variables (Wetzels, 2009). Overall, all indicators produced a high credibility of measuring the construct as each indicator has highly significant load to their respective latent construct with $99 \%$ confidence level (T-Statistic > 2.58). The CR values range from .721 to .858 , indicating acceptable reliability. The AVE values range from .547 to .634 , which exceeded the recommended threshold value of 0.50 , hence the second-order measurement model has an adequate value of the AVE.

Table 5 presents the result of the discriminant validity assessment with Fornell-Larker approach. It is indicated that all off-diagonal elements are lower than square roots of AVE, hence confirming that the discriminant validity of the measurement model based on the Fornell-Larker approach was met. This study therefore concludes that the measurement model has established its discriminant validity based on the results of the cross-loading and FornellLarker approach. As a conclusion, the reliability and validity of the second-order measurement models were satisfactory, so all items in this measurement model are valid and fit to be used to estimate parameters in the structural model. 
Table 5. Fornell-Larker Assessment of the Second-Order Measurement Model

\begin{tabular}{cccc}
\hline & ATM & CI & PPI \\
\hline ATM & .742 & & TAS \\
\hline CI & .554 & .769 & .796 \\
\hline PPI & .473 & .487 & .460 \\
\hline TAS & .558 & .597 & .740 \\
\hline
\end{tabular}

Table 6. The Coefficient of Determination

\begin{tabular}{ccc}
\hline Variable & Coefficients & Remarks \\
\hline TAS & 0.212 & Average \\
\hline ATM & 0.415 & Average \\
\hline
\end{tabular}

Table 7. The Predictive Relevance $\left(\mathrm{Q}^{2}\right)$

\begin{tabular}{|c|c|c|c|c|}
\hline Exogenous Variable & Endogenous Variable & $Q^{2}$ & Remark & Overall Predictive \\
\hline $\mathrm{PPI}$ & TAS & 0.115 & Medium & \multirow{4}{*}{ Yes } \\
\hline $\mathrm{Cl}$ & \multirow{3}{*}{ ATM } & \multirow{3}{*}{0.219} & \multirow{3}{*}{ Medium } & \\
\hline TAS & & & & \\
\hline PPI & & & & \\
\hline
\end{tabular}

Note: Omission distance was at 9 omissions.

\section{Assessment of the Structural Model}

The validity of the structural model is assessed using the coefficient of determination, predictive relevance $\left(Q^{2}\right)$, and path coefficients. Table 6 presents the Coefficient of Determination. This value indicates the amount of variance in each dependent variable that is explained by the independent variables. Thus, a larger value shows increasing predictive ability of the structural model. According to Hair et al. (2011), a value of around 0.67 is considered substantial, whereas values around 0.33 are average and values of 0.19 and lower are considered weak.

The Stone-Geisser's $\left(Q^{2}\right)$ is the predominant measure utilized to measure the predictive relevance in order to assess the research model's capability to predict (Hair et al., 2014). $Q^{2}$ is generally estimated using an omission distance of 5-10 in PLS (Hair et al., 2014). Hair et al. (2014) also noted that, the omission distance has to be chosen so that the number of observation divided by the omission distance chosen in the model estimation should not be an integer. Therefore, omission distance of 9 will be chosen since it does not produce an integer value of the model estimation. If the $Q^{2}$ values are larger than zero, this indicates that the exogenous constructs have predictive relevance for the endogenous construct (Hair et al., 2014). The result showed that all the $Q^{2}$ values were above zero. Hence all exogenous constructs in this research have predictive relevance.

Another essential point that must be evaluated for assessing the structural model in the PLS-SEM modeling approach is the effect size $\left(f^{2}\right)$ assessment (Hair et al., 2014; Ringle et al., 2013; Ziggers \& Henseler, 2009). Traditionally, $f^{2}$ value assesses the degree of the impact of specified exogenous latent variables toward the endogenous latent variables by measuring the degree of the $R^{2}$ change on the endogenous latent variables (Ziggers $\&$ Henseler, 2009). A guideline for assessing the impact of the effect size has been proposed by Cohen (1988), where the $f^{2}$ value of $0.02,0.15$, and 0.35 can be viewed as the small, medium, and large effect size of the exogenous latent variable toward the endogenous latent variable. The results indicate that the exogenous latent construct of $\mathrm{CI}\left(f^{2}=\right.$ $.067)$, PPI $\left(f^{2}=.067\right)$, and TAS $\left(f^{2}=.096\right)$ have small effect sizes towards the endogenous latent construct ATM, whereas the exogenous latent construct PPI $\left(f^{2}=.269\right)$ gives a relatively moderate predictive relevance effect towards the endogenous latent construct TAS.

The structural model represents the relationships between the latent variables that were hypothesized in the research model (Ringle et al., 2013). Table 8 lists down the path coefficients, observed $t$-value, and significance level for all hypothesized paths. The path analysis is used to determine whether the hypotheses are supported or not. The analysis showed that CI (Path coefficient $=0.277, t=5.043, p<.01$ ), PPI (Path coefficient $=0.199, t=3.429, p$ $<.01$ ) and TAS (Path coefficient $=0.300, t=5.414, p<.01$ ) were significantly positively correlated with ATM. In addition, the analysis revealed that, PPI was positively significantly correlated toward TAS (Path Coefficient $=$ $0.460, t=7.465, p<.01)$. Therefore all the hypotheses in the study have been supported by the data. 
Table 8. Path Coefficients of the Structural Model

\begin{tabular}{cccc}
\hline Path & Path Coefficient & T- statistics & $\boldsymbol{p}$-value \\
\hline $\mathrm{CI} \rightarrow$ ATM & 0.277 & 5.043 & $.001^{\star \star}$ \\
\hline $\mathrm{PPI} \rightarrow$ ATM & 0.199 & 3.429 & $.001^{\star \star}$ \\
\hline $\mathrm{PPI} \rightarrow$ TAS & 0.460 & 7.465 & $.001^{\star \star}$ \\
\hline TAS $\rightarrow$ ATM & 0.300 & 5.414 & $.001^{\star \star}$ \\
\hline
\end{tabular}

Note: ${ }^{* \star}$ the indicator loadings was significant at $99 \%$ confidence level if t-statistic $>2.58(p<.01)$; NS = Not Significant.

\section{DISCUSSION}

Perceived parental influences and teacher affective support show positive relationships towards ATM. This study coincides with findings from Reyes and Stanic (1988), Gunderson et al. (2012), Sakiz (2012), and Mohd Ali (1995). The importance of parental attitudes in determining attitudes of children is supported by the social cognitive theory (Bandura, 1977) and previous research (Ortiz, 2005; Similarly, Wachira (2005) also found teacher emphasis on increasing students' interest in mathematics and teacher's expectations to be strong predictors of students' positive attitude towards mathematics. Possible reasons are the indisputable role of teachers and parents as socializers (Wigfield \& Eccless, 2000) i.e. role models that the students look up to and try to emulate.

TAS was also found to mediate the relationship between PPI and ATM. This finding empirically supports the claim by Redding (2010) that the context of family and community are critical to a child's school learning. According to Redding (2010), the school is not impotent in affecting beliefs and behaviours of adults outside the school who influence the child's learning and development. The Education Ministry in Malaysia also has recognized this and is currently working with schools through the Sarana Ibubapa (Parental Advice) program to encourage parents' participation in their children's studies.

Classroom instruction shows a positive relationship with ATM. This finding is supported by the CLT theory which states that the aim of instructional design is to facilitate the acquisition of knowledge (Sweller, Ayres, \& Kalyuga, 2011). Therefore, the design of classroom instruction should also aim to reduce the cognitive load faced by students. The findings from this study tallies with the findings of Birgin et al. (2010). Birgin et al. (2010) carried out a study involving 220 Turkish students and found that the enjoyment of the teaching method and help with mathematics from parents has a significant negative effect on mathematics anxiety. One possible reason is that students these days are exposed to technology (tab, handphone, laptop) at a very young age. Traditional methods of teaching via chalk and talk may no longer be able to grab the curiousity and attention of these kids.

\section{CONCLUSION}

The results showed that perceived parental influences, teacher affective support, and classroom instruction are significant predictors of attitude toward mathematics. The research model was able to predict the interrelationships of the constructs on a moderate level. The findings are in line with past findings that these three constructs are important and significant predictors of attitude towards mathematics. Nevertheless, the moderate predicting relevance and effect size implied that attitude towards mathematics is multi-faceted with a likelihood of other contributing factors such as students' socio-economic status, gender and past achievements. Therefore, the relational model developed and supported with PLS analysis can be studied further with additional constructs.

\section{REFERENCES}

Abu Bakar, K. A., Tarmizi, R. A., Nor, S. M., Ali, W. Z. W., Hamzah, R., Samad, A. A., \& Jamian, A. R. (2010). Teachers and learner's perspectives on learning mathematics for at-risks students. Procedia - Social and Behavioral Sciences, 8(C), 393-402. doi:10.1016/j.sbspro.2010.12.055

Aliasgari, M., Riahinia, N. \& Mojdehavar, F. (2010). Computer-assisted instruction and student attitudes towards learning mathematics. Education, Business and Society: Contemporary Middle Eastern Issues, 3(1), 6-14 doi:10.1108/17537981011022779

Author, \& Khoo, C.H. (2010). A Structural model to predict mathematics achievement among form one students of Sabah, Malaysia. A Structural Equation Modeling approach. In Boorer et al. (Eds.) Bridging worlds: Making connections in education. International Conference on Education ICE 14th: 2009: Bandar Seri Begawan.

Bandura, A. (1977). Social learning theory. Engelwood Cliffs, New Jersey: Prentice Hall.

Berends, M., Goldring, E., Stein, M., \& Cravens, X. (2012). Instructional conditions in charter schools and students' mathematics achievement gains. American Journal of Education, 116(3), 303-335. 
Bhattacherjee, A. (2012). Social science research: Principles, methods, and practices. Open Access Textbooks. Book 3. Retrieved on 12.2.16 from http://scholarcommons.usf.edu/oa_textbooks/3

Bilican, S., Demirtasli, R. N., \& Kilmen, S. (2011). The attitudes and opinions of the students towards mathematics course: The comparison of TIMSS 1999 and TIMSS 2007. Educational Sciences: Theory E Practice, 11(3), 12771284 .

Cai, J., Moyer, J.C., \& Wang, N. (1997). Parental roles in students' learning of mathematics. Paper presented at the Annual Meeting of the American Educational Research Association, Chicago. ED 412087

Cao, Z., Bishop, A., \& Forgasz, H. (2006). Perceived parental influence on mathematics learning: A comparison among students in China and Australia. Educational Studies in Mathematics, 64, 85-106. doi:10.1007/s10649006-9033-5

Charalambous, C. Y., Panaoura, A., \& Philippou, G. (2009). Using the history of mathematics to induce changes in preservice teachers' beliefs and attitudes: Insights from evaluating a teacher education program. Educational Studies in Mathematics, 71(2), 161-180. doi:10.1007/s10649-008-9170-0

Chen, Z.-H., Liao, C. C. Y., Cheng, H. N. H., Yeh, C. Y. C., \& Chan, T.-W. (2012). Influence of game quests on pupils' enjoyment and goal-pursuing in math learning. Educational Technology and Society, 15(2), 317-327.

Chiesi, F., \& Primi, C. (2009). Assessing statistics attitudes among college students: Psychometric properties of the Italian version of the Survey of Attitudes toward Statistics (SATS). Learning and Individual Differences, 19(2). 309-313. doi:10.1016/j.lindif.2008.10.008

Chin, W.W. (1998). The partial least squares approach for structural equation modeling. In G.A. Marcoulides (Eds.), Modern methods for business research (pp. 295-236) London: Lawrence Erlbaum.

Cohen, J. (1988). Statistical power analysis for the behavioral sciences (2nd ed.). Hillsdale, NJ: Lawrence Earlbaum Associates.

Cronbach, L. J. (1971). Test validation. Educational Measurement, Issues and Practice, 2, 443-507.

Etuk, E. N., Afangideh, M. E., \& Uya, A. O. (2013). Students' perception of teachers' characteristics and their attitude towards mathematics in Oron Education Zone, Nigeria. International Education Studies, 6(2). doi:10.5539/ies.v6n2p197

Fornell, C., \& Larcker, D. F. (1981). Evaluating structural equation models with unobservable and measurement error, Journal of Marketing Research, 34(2), 161-188.

Gunderson, E. A., Ramirez, G., Levine, S.C., \& Beilock, S. L. (2012). The Role of Parents and Teachers in the Development of Gender-Related Math Attitudes. Sex Roles. 66, 153-166.

Hair Jr., J. F., Hult, G. T. M., Ringle, C. M., \& Sarstedt, M. (2014). A Primer on Partial Least Squares Structural Equation Modeling (PLS-SEM). California: SAGE Publications, Inc.

Hair, J. F., Black, W. C., Babin, B. J., \& Anderson, R. E. (2010). Multivariate data analysis (Seventh Ed.). Prentice Hall. Retrieved from http://www.cob.unt.edu/slides/Peak/Stat Books/Hair et al 2010.pdf

Hodges, C. B., \& Kim, C. (2013). Improving college students' attitudes toward mathematics. TechTrends, 57(4), 5966. doi:10.1007/s11528-013-0679-4

Hosack, L. B. (2006). The effects of hands-on instructional strategies on fourth grade students' attitudes and performance in mathematics. University of Central Florida.

Hulland, J. (1999). Use of partial least squares (PLS) in strategic management research: A review of four recent studies. Strategic Management Journal, 20, 195-204.

Jacobs, J. E., Davis-Kean, P., Bleeker, M., Eccles, J.S., \& Malanchuk, O. (2005). I can but I don't want to. in Gallagher, A.M., \& Kaufman, J.C. (Eds.) Gender Differences in Mathematics. 246 - 263. Cambridge University Press.

Jarvis, C. B., Mackenzie, S. B. \& Podsakoff, P. M. (2003). A critical review of construct indicators and measurement model misspecification in marketing and consumer research. Journal of Consumer Research, 30.

Johnson, B. (2000). Investigation of the factors affecting attitudes toward mathematics of students in different college mathematics courses. Ohio University.

Kerr, Z. (2007). Parental influences on mathematics achievement of children of immigrant backgrounds. The University of British Columbia.

Lewis, B. R., Templeton, G. F., \& Byrd, T. A. (2005). A methodology for construct development in MIS research. European Journal of Information Systems, 14, 388-400.

Lipnevich, A. A., Maccann, C., Krumm, S., Burrus, J., \& Roberts, R. D. (2011). Mathematics attitudes and mathematics outcomes of U.S. and Belarusian middle school students. Journal of Educational Psychology, 103(1), 105-118. doi:10.1037/a0021949 
Lubienski, S. T., Lubienski, C., \& Crane, C. C. (2012). Achievement differences and school type: The role of school climate, teacher certification, and instruction. American Journal of Education, 115(1), 97-138.

Mackenzie, S. B., Podsakoff, P. M., \& Jarvis, C. B. (2005). The problem of measurement model misspecification in behavioural and organizational research and some recommended solutions. Journal of Applied Psychology. 90(4).

Mahamood, S. F., Tapsir, R., Saat, A., Ahmad, S., Wahab, K. A., Boon, M. H. A., \& Rahman, K. A. (2012). Parental attitude and involvement in children's education: A study on the parental aspiration among form four students in Selangor. Procedia - Social and Behavioral Sciences, 42), 117-130. doi:10.1016/j.sbspro.2012.04.173

Marchis, I. (2011). Factors that influence secondary school students' attitude to mathematics, Procedia Social and Behavioural Sciences. 29, 786-793. doi:10.1016/j.sbspro.2011.11.306

Ministry of Education Malaysia (2012). Malaysia Education Development Plan 2013-2025, Kuala Lumpur: Ministry of Education.

Moenikia, M., \& Zahed-Babelan, A. (2010). A study of simple and multiple relations between mathematics attitude, academic motivation and intelligence quotient with mathematics achievement. Procedia-Social and Behavioral Sciences, 2, 1537-1542. doi:10.1016/j.sbspro.2010.03.231

Mullis, I. V. S., Martin, M. O., Foy, P., \& Arora, A. 2012. TIMSS 2011 International Results in Mathematics. TIMSS \& PIRLS International Study Center.

Mullis, I. V. S., Martin, M. O., Foy, P., \& Hooper, M. (2016). IEA's Trends in International Science and Mathematics Study. Retrieved from http:/ / timss2015.org/download-center at 7:25 p.m. on 01.09.2017

Nunnally, J. C., \& Bernstein, I. R. (1994). Psychometric Theory (3rd edition). New York: McGraw-Hill.

Poffenberger, T., \& Norton, D. (1959). Factors in the formation of attitudes toward mathematics. The Journal of Educational Research, 52(5), 171-176.

Reyes, L. H., \& Stanic, G. M. A. (1988). Race, sex, socioeconomic status, and mathematics. Journal for Research in Mathematics Education, 19(1), 26-43.

Ringle, C., Wende, S., \& Will, A. (2004). SmartPLS 2.0.M3. Retrieved from http:/ /www.smartpls.de

Sakiz, G. (2007). Does teacher affective support matter? An investigation of the relationship among perceived teacher affective support, sense of belonging, academic emotions, academic self-efficacy beliefs, and academic effort in middle school mathematics classrooms. Ohio State University.

Sakiz, G., Pape, S. J., \& Hoy, A. W. (2012). Does perceived teacher affective support matter for middle school students in mathematics classrooms? Journal of School Psychology, 50(2), 235-255. doi:10.1016/j.jsp.2011.10.005

Schukajlow, S., Leiss, D., Pekrun, R., Blum, W., Muller, M., \& Messner, R. (2012). Teaching methods for modelling problems and students' task-specific enjoyment, value, interest and self-efficacy expectations. Educational Studies in Mathematics, 79, 215-237. doi:10.1007/s10649-011-9341-2

Singh, S. P., \& Imam, A. (2013). Effect of personal and institutional variables on mathematics achievement of secondary school students. IOSR Journal of Humanities and Social Science, 10(3), 22-33.

Straub, D., Boudreau, M.-C., \& Gefen, D. (2004). Validation guidelines for IS positivist research. Communications of the Association for Information Systems, 13, 380-427.

Sweller, J., Ayres, P., \& Kalyuga, S. (2011). Cognitive Load Theory. Springer Science+Business Media.

Tahar, N. F., Ismail, Z., Zamani, N. D., \& Adnan, N. (2010). Students' attitude toward mathematics: The use of factor analysis in determining the criteria. Procedia - Social and Behavioral Sciences, 8, 476-481. doi:10.1016/j.sbspro.2010.12.065

Tapia, M. (1996). The Attitudes toward Mathematics Instrument. Paper presented at the Annual Meeting of the Mid-South Educational Research Association. Tuscaloosa, AL.

Tapia, M., \& Marsh, G. E. (2000). Effect of gender, achievement in mathematics, and ethnicity on attitude towards mathematics. In Annual Meeting of the Mid-South Educational Research Association. Bowling Green, KY.

Tessema, T. G. (2010). Classroom instruction and students' attitudes towards mathematics. Arizona State University.

Urbach, N., \& Ahlemann, F. (2010). Structural equation modeling in information systems research using partial least squares. Journal of Information Technology Theory E Application, 11, 5-40.

Wigfield, A., \& Eccles, J.S. (2000). Expectancy-value theory of achievement motivation. Contemporary Educational Psychology, 25, 68 - 81. doi:10.1006/ceps.1999.1015

Woon, Peggy H.Y. (2005). Hubungan antara Sikap terhadap Matematik dengan Pencapaian Matematik Pelajar Tahun Tiga. Tesis Sarjana Pendidikan. Fakulti Pendidikan. Universiti Malaya. 
Yang, X. (2015). Rural junior secondary school students' perceptions of classroom learning environments and their attitude and achievement in mathematics in West China. Learning Environments Research. 18(2), 249-266.

Ziggers, G.W. \& Henseler, J. (2009). Inter-firm network capability: How it affects buyer-supplier performance. British Food Journal, 111(8). $794-810$.

http://www.ejmste.com 